\title{
Micro Hydropower System Design for Gua Kelam Electricity Supply
}

\author{
Mahmoud A. M. Albreem ${ }^{1}$, Rosnita Md Aspan ${ }^{2}$ \\ ${ }^{1}$ Department of Electronics and Communication Engineering, A’Shariqyah University, Oman \\ ${ }^{2}$ School of Electrical Systems Engineering, University Malaysia Perlis, Malaysia
}

\begin{tabular}{l}
\hline Article Info \\
\hline Article history: \\
Received Feb 19, 2018 \\
Revised Apr 25, 2018 \\
Accepted May 10, 2018 \\
\hline
\end{tabular}

Keyword:

Flow rate

Hydraulic turbin

Hydropower system

\begin{abstract}
Sufficient and uninterrupted electricity supply is one of the main factors to develop the country. Today, electricity can be generated using a variety of sources, whether from non-renewable sources as well as renewable resources. To generate electrical power, Malaysia can't rely entirely on nonrenewable resources such as petroleum and coal as these are finite resources which are experiencing depletion around the world. Electricity generated from renewable sources such as water, particularly from micro hydropower systems is considered the cheapest and most environmentally friendly source of electrical energy. Based on the reconnaissance study conducted, the streams of flowing water in Gua Kelam have the potential to yield about $34.29 \mathrm{~kW}$ of electricity power, based on the head height of $27 \mathrm{~m}$ and flow rate $0.216 \mathrm{~m} 3 / \mathrm{s}$. In this paper, a model for an ordinary micro hydropower facility has been proposed. It links various electromechanical equipment consisting of a hydraulic turbine governor, and a synchronous generator. The modeling was executed to design a micro hydropower system as an alternative source of supply of electricity to Gua Kelam, Perlis. The proposed model was tested by placing a three-phase fault to earth for the purpose of testing the reliability of the system. With the selection of an appropriate control system, the proposed model is very suitable for the development of micro hydropower system at a potential site such as Gua Kelam.
\end{abstract}

Copyright (ङ) 2018 Institute of Advanced Engineering and Science. All rights reserved.

\section{Corresponding Author:}

Mamoud A. M. Albreem,

Departement of Electronics and Communication Engineering,

A'Sharqiyah University,

400 Ibra, Oman.

Email: Mahmoud.albreem@asu.edu.om

\section{INTRODUCTION}

Leading countries are focusing on the enhancement of many alternative and renewable energy resources since fossil fuels can no longer fulfill the world's ever increasing energy demands [1]. An ideal energy source should be renewable and should have minimal effect on environment [2].

Technology that utilizes the head of water flowing in a stream to generate electrical power when the water turns a turbine is known as a micro hydropower (MHP), a well-tested technology once relied by some developed nations for power supply before venturing into large-scale hydropower systems [3]. Various studies carried out have led to improvements to make MHPs viable for development, especially in remote areas that are difficult to get electricity from the grid.

Gua Kelam is located $33 \mathrm{~km}$ north of Kangar, is a limestone cave that has now become a tourist attraction. The existence of a river, Sungai Pelarit, flowing through the cave and then flows into the Sungai Perlis highlight proposals to develop the potential micro hydro plant in the area. These areas were supplied with electricity from the National Grid but it is undeniable that there are only goodness to be gained from the application of a MHP system, making the study of Gua Kelam as a potential MHP plant feasible. 
MHP is reputedly one of the most efficient, longest lasting and most reliable forms of renewable energy for electricity generation [4]. Comparing what a MHP plant has over other power generation systems of the same capacity (from wind, wave and solar power plants) is that it has an efficiency range of $70 \%$ to $90 \%$ which is the best that any other energy technology can achieve [5]. With the combination of the hilly terrain and an extensive river network, a micro hydropower plant can be developed in areas with potential. With today's advancing technology and the many studies conducted, generating electricity from the kinetic energy in rivers in flat areas that were previously impossible to implement is now possible. The operating life of a MHP plant can last up to 50 years if the system is well-installed and maintained [6].

Currently, Malaysia's electricity generation depends on fossil fuels. It's reliance, which is around $90 \%$, is not a secure option in the long run [7]. The nation's oil reached a peak of 862,000 bbl/d in 2004 and production has been gradually decrementing ever since, primarily due to maturing oil reservoirs [8]. To ensure sustainability in the development of it's oil reserves, it has become an important issue for the governments to establish new economically worthy sources of energy as the supply of fuels are gradually depleting and alternative costs and the maintenance remains increasing yearly making it harder for Malaysia to sustain its oil development [9]. Malaysia is rich in renewable energy sources such as biogas, biomass, solar, wind and hydro. Among these sources of renewable energy, the potential of developing more efficient MHP systems seems most underexplored.

This paper proposes MHP model for electricity supply in Gua Kelam as an alternative source to supply electricity to areas that have the potential to reduce dependence on fossil fuels as the main source to generate electricity. However, map studies and hydrology studies used to identify potential Gua Kelam as a site to develop MHP system. The rest of the paper designed a model inclusive of the components to be located in the powerhouse, which are the hydraulic turbine and governor, and the synchronous generator. It does not involve designing civil works components such as intake, forebay tank, penstock and so on. The modeling is done using block diagrams with a graphical interface and a set of blocks with signal interconnections. The model eventually was tested using Matlab/Simulink to investigate the effectiveness of the proposed models.

\section{BACKGROUND}

Micro hydro power systems are included in the category of small scale hydro plants. According to Practical Action, MHP generation capacity is in the range of $5 \mathrm{~kW}$ to $100 \mathrm{~kW}$ [4]. There are two very important parameters related to the MHP, these are head and water flow rate. Both are not only used when making an assessment to identify the potential of a MHP site, but it also important for the purpose of designing and selecting an appropriate hydropower system on the site [3].

Because water is diverted from the stream or river and redirected back into the same stream with relatively little impact on the surrounding ecology, a micro hydro plant is considered a 'run-of-river' system [10]. Power is generated only when enough water is available from the river or stream because this type of scheme does not have any water storage capability. Often MHP system considered a standalone system for small power capacity and just enough for local consumption. Standalone system means the system is off-grid, which is not connected to the grid line system [4]. Figure 1 shows a typical layout of MHP system.

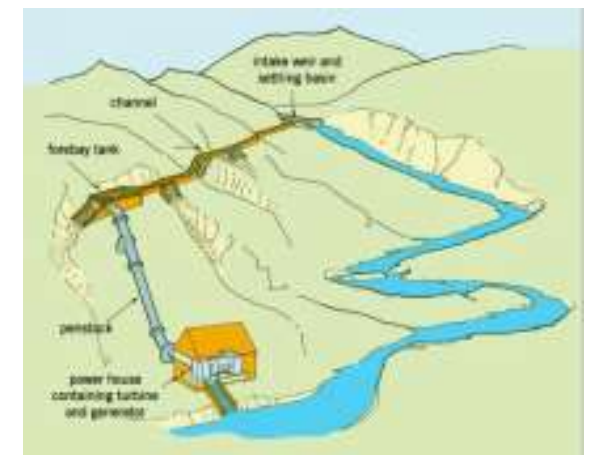

Figure 1. A Typical micro hidropower system configuration [4]

The major parts of a typical micro hydro power system are [11]:

1. Water diversion (Intake)

2. Pipeline (Penstock) 


\section{POWERHOUSE}

Conveyance of water from the source of water in required quantity towards the waterways is the primary means of a hydro power intake. To prevent large water born objects from entering the waterway of the MHP project, trash racks have to be placed at the intake which acts as the filter [12]. Pipeline is responsible to convey the water from forebay tank to the turbine. It pressurises the water and must be capable of withstanding high pressures. Powerhouse is a building that consists of electro-mechanical equipment such as turbines, generator, drive systems and controllers [13]. Turbine is the primary component in the MHP system that converts the energy from falling water into mechanical rotating shaft power [14]. Depending on the speed required for the generator, the turbine can be connected either directly to the generator or indirectly by means of gears or belts and pulleys [13]. Then, generator produces electric energy.

Turbines can be divided into two major types: reaction turbine and impulse turbine [14]. The most common types of turbine used in micro hydro system included in the reaction turbine are Francis, Kaplan and Propeller turbine [14]. Often the reaction turbine is used for low head against the impulse turbine [11], meanwhile an impulse turbine is used in high head and medium head plants [15]. Pelton, Turgo and Crossflow are the most common impulse turbine used in micro hydro system [14].

\section{METHODOLOGY}

\subsection{Identify Gua Kelam as a potential base to develop micro hydropower system}

\subsubsection{Reconnaissance studies}

Reconnaissance studies were carried out to identify Gua Kelam as a potential site to develop micro hydropower plant. A preliminary study to identify hydropower potential sites is called a reconnaissance study during the initial stages [16]. The reconnaissance study is divided into two main parts, namely, map studies and hydrology studies. The topographic map of the area around Kaki Bukit and meteorological data from the nearest meteorological station (Chuping Station) was used for both of these studies.

From the map studies, the suitable stream, head, catchment area and waterway route were identified for micro hydro generation [16]. The available head is estimated by determining the difference in elevation between the possible intake and tailrace of the site.

Since there are no flow records at a particular location, the stream flow available for micro hydro generation was predicted by estimating the mean annual flow $\left(Q_{m}\right)$. The catchment water balance methodology was used to estimate $Q_{m}[17]$.

$$
Q_{m}=(A A R D \times \text { Area }) / 31536
$$

where $Q_{m}$ is mean annual flow $\left(\mathrm{m}^{3} / \mathrm{s}\right), A A R D$ is average catchment run-off depth $(\mathrm{mm})$ and Area is catchment area $\left(\mathrm{km}^{2}\right)$.

The long term average annual catchment runoff depth $(A A R D)$ is given by [17]:

$$
A A R D=S A A R-A E
$$

where $S A A R$ is standard average annual rainfall $(\mathrm{mm})$ and $A E$ is actual evaporation $(\mathrm{mm})$. The relationship between $r$ and $S A A R$ is given by:

$$
\begin{aligned}
& r=0.00061 \times S A A R+0.475 \text { for } S A A R<850 \mathrm{~mm} \\
& r=1.0 \quad \text { for } S A A R>850 \mathrm{~mm}
\end{aligned}
$$

Actual evaporation is calculated using:

$$
A E=r \times P E
$$

where $r$ is scaling factor and $P E$ is potential evaporation (mm).

To estimate $S A A R$ and potential evaporation, rainfall and daily potential evaporation data $(P E)$ are used. The annual rainfall and daily evaporation data used were obtained from Malaysian Meteorological Department (Chuping Station) from period of 2005 to 2014. The average annual evaporation and average annual rainfall for the 10 years were calculated first before the daily evaporation data could be derived and used for hydrology studies [18].

Even though the approaches for estimating mean annual flow may not be precise, the value obtained is reliable enough to estimate the total available hydraulic energy on the specified site [19]. 


\subsubsection{Estimation of power generation}

The estimated total available power of the site were calculated using the estimated head and flow rate obtained from map studies and hydrology studies [20]. An efficiency factor of 0.6 was selected to estimate the realistic power available from the site as shown in (6). The value 0.6 was selected based on the NRCan which states that for systems up to $10 \mathrm{~kW}$ (small systems), the efficiency factor could be taken as approximately $50 \%$. Meanwhile, for systems larger than $10 \mathrm{~kW}$ (larger systems), the efficiency factor is generally from $60 \%$ to $70 \%$ [13].

$$
P=0.6 \times Q_{m} \times g \times H
$$

where $P$ is energy change per second $(\mathrm{kW}), Q_{m}$ is volume per second of water fall down $\left(\mathrm{m}^{3} / \mathrm{s}\right), g$ is aacceleration due to gravity $\left(\mathrm{m} / \mathrm{s}^{2}\right)$ and $H$ is aavailable head $(\mathrm{m})$.

\subsubsection{Power demand determination}

Power demand survey is important in the planning of electrification system. This is to ensure that the power generated by the plant is sufficient to meet the needs of the area [21]. To identify the power demand in the area, all utilities are estimated using pre-designed analysis format.

\subsection{Modeling of micro hydropower system plant}

This paper describes the modeling of the two electro-mechanical components of MHP system that is found in powerhouse, which are the hydraulic turbine and governor and the synchronous generator.

\subsubsection{Hydraulic turbine and governor}

Hydraulic turbine and governor basically used for two purposes: firstly, it develops mechanical power at the shaft of the generator which is fed to the generator for production of electricity, and secondly to control the variation of speed of the generator such that the generated frequency remains constant. In this paper, the simple hydraulic systems governed by proportional-integral-derivative and proportional-integral controllers are modeled. The hydraulic turbine and governor system consists of a hydraulic turbine, a servomotor and a PID-based governor, as illustrated in Figure 2.

The hydraulic turbine is modeled by the nonlinear system illustrated in Figure 3 . The parameter beta is the speed deviation damping coefficient. Pm indicates the initial mechanical power in per unit at the machine's shaft. This value is automatically updated by the load flow utility of the Powergui block [22].

The gate servo motor is modeled by a second-order system as shown in Figure 4. The electric servo motor is used as a governor. As they have a simple design, require less maintenance and are less expensive than conventional governors, the electric servo motors are preferable for the control of micro hydropower systems [23]. The gain, Ka and time constant, Ta in seconds $(s)$, of the first-order transfer function representing the servo motor [24].

Turbine speed governor Proportional Integral Derivative (PID) gains play a very important role on hydraulic transient caused by load changes [25]. The PID describe three basic mathematical functions applied to the error signal. The PID regulator has a proportional gain $\mathrm{K}_{\mathrm{p}}$, an integral gain $\mathrm{K}_{\mathrm{i}}$, and a derivative gain $\mathrm{K}_{\mathrm{d}}$. The use of high derivative gain leads to oscillations or instability in the case of connection to a strong interconnected system. PID controllers ensure faster speed response by providing both transient gain reduction and increase. The transfer function of PID without derivative part (PI governor) is actually equivalent to the hydraulic-mechanical governor [26]. The model of PID subsystem is shown as Figure 5.

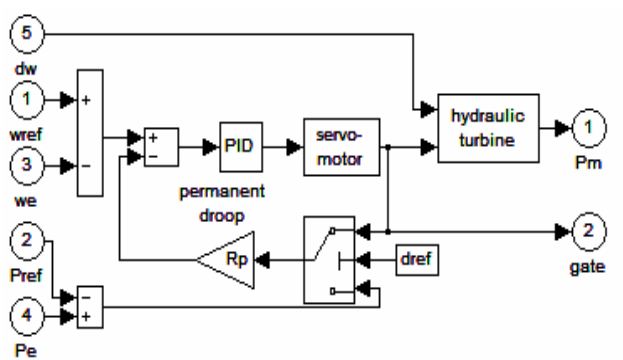

Figure 2. Hydraulic turbine and governor model

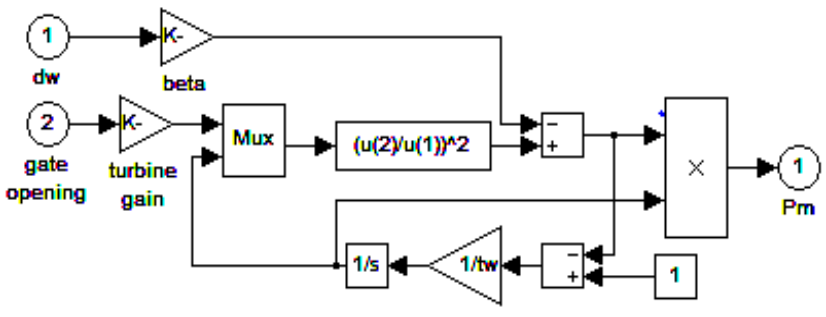

Figure 3. Hydraulic turbine model 


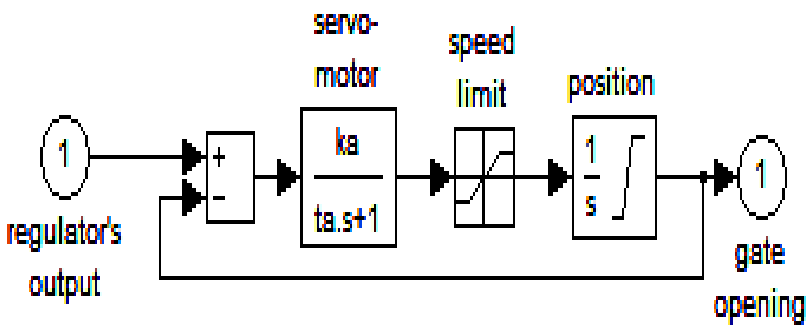

Figure 4. Model of a gate servo motor

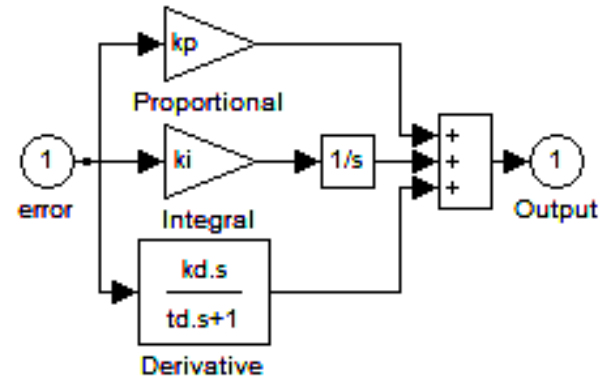

Figure 5. Model of PID subsystem

Values of $K_{p}, K_{i}, K_{d}$ and $T_{w}$ can be calculated using (7) to (9) [27]:

$$
K_{p} \quad=\frac{1}{R_{t}}
$$

where $R_{t}$ is temporary droop (pu).

For $K_{i}$ :

$$
K_{i} \quad=\frac{K_{p}}{T_{r}}
$$

where $T_{r}$ is dashpot time constant (s). By using PI governor, $K_{d}=0$, where $T_{w}$, called water time constant or water starting time (in $s$ ) is calculated as (9).

$$
T_{w} \quad=\frac{q_{r} L}{A h_{r} g}
$$

where $q_{r}$ is rated turbine flow $\left(\mathrm{m}^{3} / \mathrm{s}\right), L$ is penstock length $(\mathrm{m}), A$ is penstock cross section $\left(\mathrm{m}^{2}\right)$ and $h_{r}$ is rated turbine head $(\mathrm{m})$.

\subsubsection{Synchronous machine}

The generator used to simulate the power production from a MHP generator is a three-phase salient pole synchronous generator. The power stability of a system mainly depends on the performance of the synchronous generator. The variation of load or frequencies of synchronous machines pull the system toward instability [28-29]. Salient pole synchronous generators are mostly used in hydro power plants compared to cylindrical rotors which are commonly used in nuclear, gas and thermal power plants.

\subsection{Operation of micro hydropower plant}

Figure 6 shows the flowchart of the proposed model for a micro hydropower plant in Gua Kelam, while Figure 7 illustrates the proposed model of a micro hydro plant.

The micro hydropower plant is established in an area where there is a relatively high water catchment area which is the source of water to drive a turbine. Water collected from the watershed is filtered and channeled into a forebay tank which then conveys the water to the turbine through a penstock. Water from the forebay tank will flow into the hydro turbine and governor system through a wicket gate.

The hydro turbine and governor system has three components, which are the hydro turbine, the governor and the hydro servo motor. These individual parts play an important role in stabilizing the system. The hydraulic turbine is used to convert mechanical energy from the potential energy of the water in the forebay via gravity, which than drives the synchronous generator. To generate the excitation voltage supplied to the synchronous generator, an excitation system is used.

The actual speed of the synchronous generator is compared to the reference speed. If there is a difference between these two speeds, then this difference will act as an input to the governor. The output signal from the governor send a signal to the servo motor. For example, if the shaft speed is greater than the reference value, governor sends a signal to servo motor system to reduce wicket gate opening. When wicket 
gate opening is reduced, the flow rate will automatically be reduced. Then, the mechanical power developed at the turbine output will be reduced. Consequently, the shaft speed is reduced and the system will resume at a synchronous speed. On the other hand, if the synchronous speed is equal to the reference speed, the system will generate power at a constant speed. A $20 \mathrm{~kW}$ output is the resultant load produced at the end. To test the reliability of the system, a three-phase fault block is connected to the load.

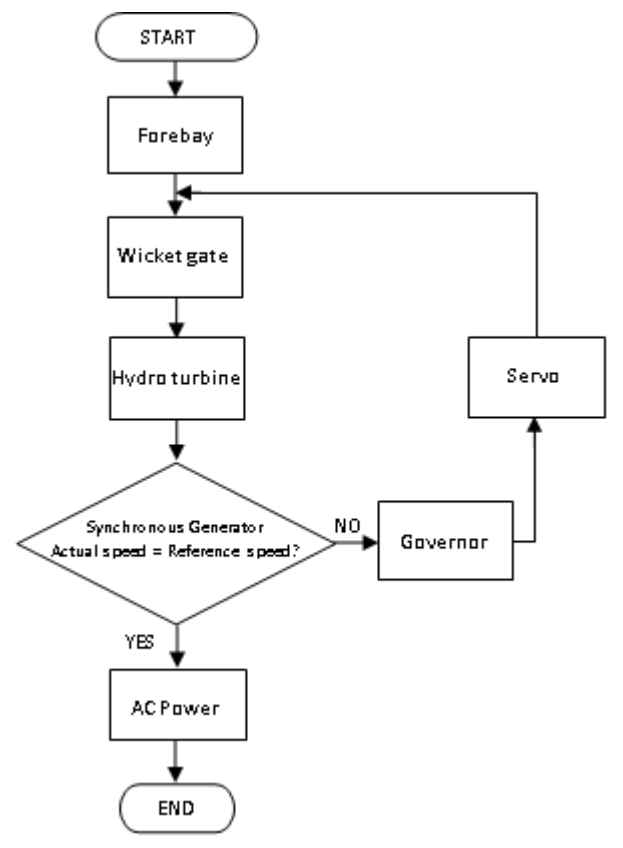

Figure 6. Flowchart of proposed model of micro hydropower plant

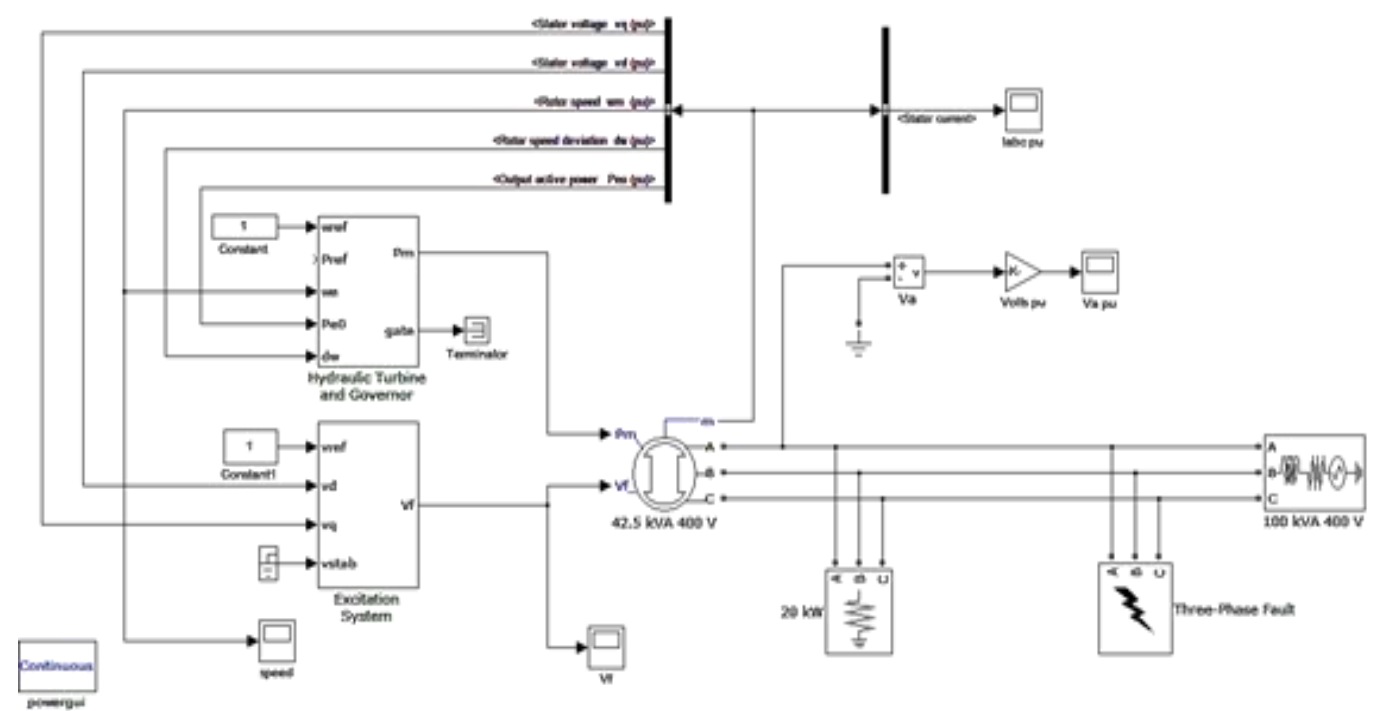

Figure 7. Proposed model of micro hydropower plant

\section{RESULTS AND DISCUSSION}

\subsection{Identify Gua Kelam as a potential base to develop micro hydro system}

The available head, $H$, and catchment area (Area) are estimated from topographic map of Kaki Bukit provided by the Department of Survey and Mapping Malaysia. The available head and catchment area were found to be $27 \mathrm{~m}$ and $12 \mathrm{~km}^{2}$, respectively. Power generation can be obtained at Gua Kelam calculated using (6). 


$$
\begin{aligned}
& P=(0.6)(216)(9.8)(27) \\
& =34.29 \mathrm{~kW}
\end{aligned}
$$

From the total power generation raised, the estimated total daily energy, $E_{\text {Gdaily }}$, is calculated:

$$
\begin{aligned}
\mathrm{E}_{\text {Gdaily }} & =34.29 \mathrm{~kW} \times 24 \mathrm{~h} \\
& =822.96 \mathrm{kWh}
\end{aligned}
$$

Gua Kelam is a tourist attraction under the management of the Perlis Forestry Department. Therefore, it is not a densely populated area. Under the management of the department, there is a building that became a centre for the management of the area. Electricity equipment that is used only covers

\begin{tabular}{|c|c|c|c|c|c|c|}
\hline Item & $\begin{array}{c}\text { Power rate per unit } \\
\text { (W) }\end{array}$ & Quantity & Total power $(\mathrm{W})$ & Hours/day & days/week & Watt hr/week \\
\hline $\begin{array}{l}\text { Air conditioner } \\
3.5 \mathrm{hp}\end{array}$ & $3.5 \mathrm{k}$ & 5 & 17,500 & 4 & 5 & 350,000 \\
\hline Street light & 60 & 10 & 600 & 12 & 7 & 50,400 \\
\hline Spotlight & 100 & 4 & 400 & 24 & 7 & 67,200 \\
\hline Flourescent Light & 40 & 20 & 800 & 8 & 5 & 32,000 \\
\hline Grand Total & & & 19,300 & & & 499,600 \\
\hline
\end{tabular}
management office, street lighting and lighting in the cave. Table 1 shows the power demand profile analysis for the Gua Kelam.

Table 1. Power Demand Profile Analysis for Gua Kelam

From Table 1, the maximum total power used at any one time is $19.3 \mathrm{~kW}$ while the weekly energy consumption, $E_{D \text { weekly }}$, was $499.6 \mathrm{kWh} /$ week.

The daily energy consumption, $E_{D d a i l y}$, can be obtained as:

$$
\begin{aligned}
E_{\text {Ddaily }} & =\frac{499,600 \mathrm{Wh} / \text { week }}{7 \text { days }} \\
= & 71.371 \mathrm{kWh}
\end{aligned}
$$

The total power that can be generated from the plant is $34.29 \mathrm{~kW}$ or $822.96 \mathrm{kWh}$ per day and the maximum power demand is at $19.3 \mathrm{~kW}$ or $71.371 \mathrm{kWh}$ per day. Thus it is concluded that Gua Kelam has the potential to be developed as a site for a MHP plant. For the modelling of MHP plant, the turbine and generator most suitable for use on the proposed site must be higher than $34.29 \mathrm{~kW}$.

The parameters used for hydraulic and controls are as shown in Table 2. Based on head measurement and flow rate, the MHP plant is planned to use Francis turbine with $50 \mathrm{~kW}$ rated turbine power and $400 \mathrm{~V}$ three phase synchronous generator with rating power $42.5 \mathrm{kVA}$ and frequency of $50 \mathrm{~Hz}$.

Table 2. Hydraulic and Control Parameters

\begin{tabular}{lc}
\hline \multicolumn{1}{c}{ Parameter } & Value \\
\hline Rated generator & $42.5 \mathrm{kVA}$ \\
Rated turbine power & $50 \mathrm{~kW}$ \\
Rated turbine flow, $\mathrm{q}_{\mathrm{r}}$ & $67.33 \mathrm{~m}^{3} / \mathrm{s}$ \\
Rated turbine head, $\mathrm{h}_{\mathrm{r}}$ & $27 \mathrm{~m}$ \\
Gate position at rated condition & $0.9 \mathrm{pu}$ \\
No load flow, $\mathrm{q}_{\mathrm{nl}}$ & $0.2 \mathrm{~m}^{3} / \mathrm{s}$ \\
Permanent droop, $\mathrm{R}_{\mathrm{p}}$ & $0.05 \mathrm{pu}$ \\
Temporary droop, $\mathrm{R}_{\mathrm{t}}$ & $0.8598 \mathrm{pu}$ \\
Dashpot time constant, $\mathrm{T}_{\mathrm{r}}$ & $11.0762 \mathrm{~s}$ \\
Servo motor gain, $\mathrm{K}_{\mathrm{a}}$ & 3.33 \\
Servo motor time constant, $\mathrm{T}_{\mathrm{a}}$ & $0.07 \mathrm{~s}$ \\
Max gate opening rate MXGTOR & $0.1 \mathrm{pu} / \mathrm{s}$ \\
Max gate closing rate MXGTCR & $-0.1 \mathrm{pu} / \mathrm{s}$ \\
Max gate limit, G max & $0.01 \mathrm{pu}$ \\
Min gate limit, G min & $0.97518 \mathrm{pu}$ \\
Penstock length, L & $212 \mathrm{~m}$ \\
Penstock cross section, A & $15.2 \mathrm{~m}$ \\
Turbine damping, D & $0.5 \mathrm{pu} / \mathrm{pu}$ \\
Speed deviation, $\Delta \mathrm{w}$ & $0.77211 \mathrm{pu}$ \\
\hline
\end{tabular}




\section{SIMULATION RESULTS}

Figure 8 to Figure 11 show the performance of the modelling of micro hydropower plant. Figure 8 shows the result for synchronous generator rotor speed in per unit.

From the characteristics, it is observed that the rotor speed takes 1.2 seconds to achieve a steady state condition at synchronous speed.

Figure 9 shows the field voltage characteristics of the synchronous generator. It shows that the field voltage in per unit takes 1.4 seconds to reach steady state condition.

Stator current of the synchronous generator in per unit takes 1.3 seconds to reach steady as shown in Figure 10. It also illustrates the high transient value from 0.1 second to 0.2 .

In Figure 11, it is clear that the phase voltage of synchronous generator in per unit takes 0.57 seconds to reach the steady state condition. From the observation, the phase voltage starts at 1.1 per unit in the beginning of the simulation. Then it dropped to 0 per unit when fault occurred and returned to nominal immediately after the fault is cleared.

The same occurred when the excitation system field voltage had reached the value of $11.5 \mathrm{pu}$ when fault occurred. It is shown that at fault the rotor speed increased to $1.21 \mathrm{pu}$ but returned to $1 \mathrm{pu}$ as it regulates by the governor system. The speed takes some times to stabilise due to the rate of valve opening and closing in the governor system is limited to $0.1 \mathrm{pu} / \mathrm{s}$.

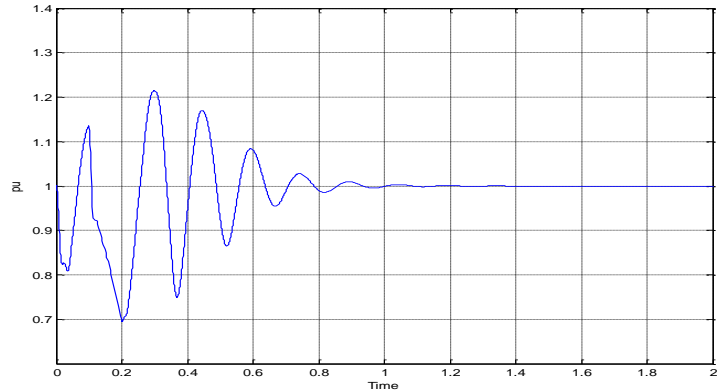

Figure 8. The synchronous generator rotor speed characteristics

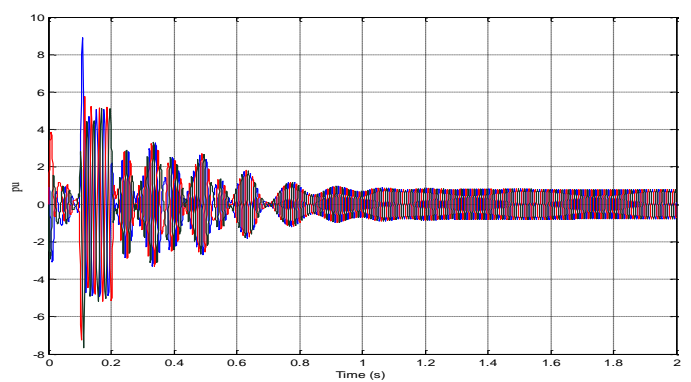

Figure 10. The stator current of synchronous generator characteristics

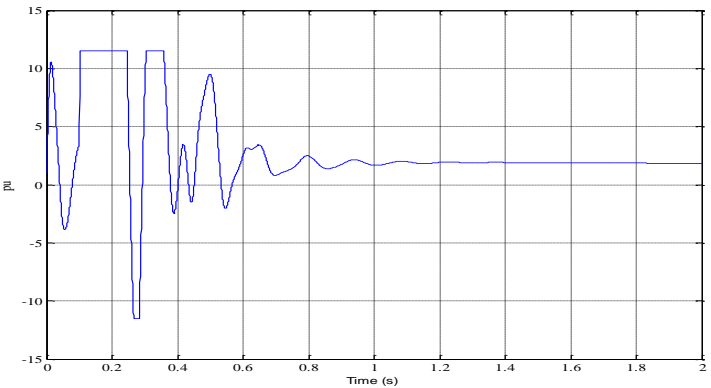

Figure 9. The synchronous generator field voltage characteristics

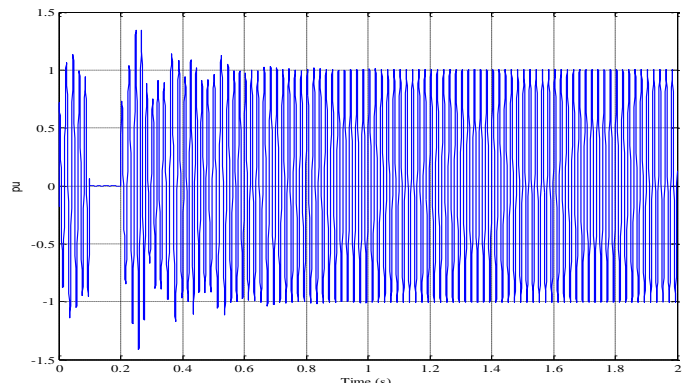

Figure 11. The Phase voltage of synchronous generator characteristics

\section{CONCLUSION}

The potential of Gua Kelam as an MHP plant have been identified. The modeling of MHP system has been developed and designed to run. The results show that with the selection of appropriate governing system, leads to constant voltage and constant output speed. The construction of an MHP plant as the main source of energy supply in Gua Kelam may not be a good idea as the area has been granted the power supply from the National Grid, but the idea of making the MHP system as an alternative source of off-grid electricity cannot continue to be ignored. This is because the cost of fossil fuel-based electricity generation is increasing day by day.

The proposed model designed for this research uses a realistic value of estimated head and flow rate in Gua Kelam, making it a more reliable model to be developed at the proposed site. 


\section{REFERENCES}

[1] El- Khattam, W., Salama, M.M.A., "Distributed generation technologies: definition and benefits,". Electric Power System Research, vol. 71, no. 2, pp. 119-128, 2004.

[2] Guney, M.S., Kaygusuz, K. "Hydrokinetic energy conversion systems: a technology status review," Renewable and Sustainable Energy Reviews, vol. 14, no. 9, pp. 2996-3004, 2010.

[3] Kaunda, C.S., Kimambo, C.Z., Nielsen, T.K. "A technical discussion on microhydropower technology and its turbines," Renewable and Sustainable Energy Reviews, vol. 35, pp. 445-459, 2014.

[4] Practical Action. "Micro-hydro power,". Retrieved March 12, 2015, from http://practicalaction.org/docs/technical_information_service/micro_hydro_power.pdf, 2013.

[5] Nasir, B.A., "Design consideration of micro-hydro-electric power station. Technologies and Materials for Renewable Energy," Environment and Sustainability, vol. 50, pp. 19-29, 2014.

[6] Paish, O., "Small hydro power: technology and current status,". Renewable and Sustainable Energy Reviews, vol. 6, no. 6, pp. 537-556, 2002.

[7] Salman, A., Razman, M.T., "Selection of renewable energy sources for sustainable development of electricity generation system using analytic hierarchy process: a case of Malaysia," Renewable Energy, vol. 63, pp. 458-466, 2014.

[8] Energy Information Administration, "Energy profile of Malaysia," Retrieved March 11, 2015, from http://www.eoearth.org/view/article/152509/, 2013.

[9] Gomesh, N., Daut, I., Irwanto, M., Irwan, Y.M., Fitra, M., "Study on Malaysian's perspective towards renewable energy mainly on solar energy," Energy Procedia, vol. 36, pp. 303-312, 2013.

[10] Alternative Energy News Network, "Micro hydro power - pros and cons," Retrieved July 29, 2015, from http://www.alternative-energy-news.info/micro-hydro-power-pros-and-cons, 2015.

[11] Canyon Hydro, "Guide to hydro power: an introduction to hydropower concepts and planning," Retrieved August 1, 2015, from http://associatiamhc.ro/wp-content/uploads/2013/11/Guide-to-Hydropower.pdf, 2015.

[12] Harper, G.D., "Planning and installing micro hydro system: a guide for installers, architects and engineers," New York: Earthscan Publications Ltd, 2011.

[13] Natural Resources Canada, "Micro-hydropower systems: a buyer's guide," Retrieved July 28, 2015, from http://www.oregon.gov/energy/RENEW/Hydro/docs/MicroHydroGuide.pdf, 2015.

[14] Asian, Pacific Center for Technology Transfer, "Micro hydro power: resource assessment handbook," New Delhi.: Singh, D, 2009.

[15] Drtina, P., Sallaberger, M., "Hydraulic turbines - basic principles and state-of-the art computational fluid dynamics application," Journal of Mechanical Engineering Science, vol. 213, pp. 85-102, 1999.

[16] Gaorong, L., Qiubo, M., "A manual of reconnaissance study for micro hydro power development," Hangzhou Regional Centre (Asia Pacific) For Small Hydro Power, 1999.

[17] European Small Hydropower Association, "Layman's guidebook on how to develop a small hydro site," (2nd ed.). Madrid: Penche, C, 1998.

[18] Raman, N., Ibrahim, H., Palanisamy, K., "Micro hydro potential in West Malaysia," Proceeding from ICEE 2009: The Third International Conference on Energy and Environment. Malacca, Malaysia, 2009.

[19] National Rural Electric Cooperative Association (NRECA) International Foundation, "Micro hydropower sourcebook," Washington, D.C: Inversin, A. R, 1986.

[20] Hurst, P., "Rainforest politics, ecological destruction in South- East Asia," London: Zeds Books, 1990.

[21] Department of Energy, "Manuals and guidelines for micro-hydropower development in rural electrification," vol. 1. Manila, Philippines: Department of Energy Philippines Office, 2009.

[22] MathWorks Group. 2009. MathWorks documentation. Retrieved August, 10, 2015, from http://www.mathworks.com

[23] Hanmandlu, M., Goyal, H., Kothari, D.P. (2006). An advanced control scheme for micro hydro power plants. Proceeding from PEDES ‘06: The International Conference on Power Electronics, Drives and Energy Systems.New Delhi, India, 2009.

[24] Alireza, K., Omer, C.O. (2010). Energy harvesting: solar, wind and ocean energy conversion systems. Florida: CRC Press, 2010.

[25] H. Fang, L. Chen, N. Dlakavu and Z. Shen, "Basic Modeling and Simulation Tool for Analysis of Hydraulic Transients in Hydroelectric Power Plants," in IEEE Transactions on Energy Conversion, vol. 23, no. 3, pp. 834841, Sept. 2008.

[26] Naghizadeh, R.A., Jazebi, S. Vahidi, B., "Modeling hydro power plants and tuning hydro governors as an education guideline," International Review on Modeling and Simulation, vol. 5, no. 4, pp. 1780-1790, 2012.

[27] Eremia, M., Shahidehpour, M., "Handbook of electrical power system dynamics: modeling, stability and control," New Jersey: John Wiley \& Sons Inc 2013.

[28] Gupta, J.B., "Performance of electrical machine," New Delhi: S.K. Kataria \& Sons., 2012.

[29] Karady, G.G., Holbert, K.E., "Electrical energy conversion and transport: an interactive computer-based approach," New Jersey: John Wiley \& Sons Inc, 2013. 